\title{
IS MOBILITY OF TECHNICAL PERSONNEL A SOURCE OF R\&D SPILLOVERS?
}

\author{
Jarle Møen
}

Working Paper 7834

http://www.nber.org/papers/w7834

\author{
NATIONAL BUREAU OF ECONOMIC RESEARCH \\ 1050 Massachusetts Avenue \\ Cambridge, MA 02138 \\ August 2000
}

I am grateful to Zvi Griliches for suggesting this topic to me, and for inviting me to visit Harvard University and NBER while working on the project. I have received useful comments from James Adams, Pierre Azoulay, Torbjørn Hægeland, Adam Jaffe, Oddbjørn Raaum, Kjell Salvanes, Scott Stern and seminar participants in Oslo and Cambridge. Finally, I am indebted to Tor Jakob Klette. The paper has benefitted greatly from his continuous advice and encouragement. Remaining errors and all opinions expressed are the sole responsibility of the author. The project is financed by the Research Council of Norway.

(C) 2000 by Jarle Møen. All rights reserved. Short sections of text, not to exceed two paragraphs, may be quoted without explicit permission provided that full credit, including $(\subset)$ notice, is given to the source. 
Is Mobility of Technical Personnel a Source of R\&D Spillovers?

Jarle Møen

NBER Working Paper No. 7834

August 2000

JEL No. J24, J31, J62, O32

\section{ABSTRACT}

Labor mobility is often considered to be an important source of knowledge externalities, making it difficult for firms to appropriate returns to R\&D investments. In this paper, I argue that inter-firm transfers of knowledge embodied in people should be analyzed within a human capital framework. Testing such a framework using a matched employer-employee data set, I find that the technical staff in R\&D-intensive firms pays for the knowledge they accumulate on the job through lower wages in the beginning of their career. Later they earn a return on these implicit investments through higher wages. This suggests that the potential externalities associated with labor mobility, at least to some extent, are internalized in the labor market.

Jarle Møen

Norwegian School of Economics and Business Administration

Department of Economics

Hellevn 30, 5045 Bergen

Norway

and Statistics Norway, Microeconometric Division

jarle.moen@nhh.no 
"Don't let your employees do to you what you did to your former boss."

The golden rule of protecting trade secrets, as defined by Intel general counsel Roger

Borovoy (Jackson; 1997)

\section{Introduction}

Labor mobility is likely to be a very important source of knowledge diffusion. Surveying one hundred founders of companies on the 1989 Inc. '500' list of the fastest growing companies in the United States, Bhide (1994) finds that 71 percent "replicated or modified an idea encountered through previous employment." With respect to technical employees, Almeida and Kogut (1996), demonstrate by an analysis of patent data from the semiconductor industry that ideas are spread through mobility of key engineers. Evidence of this kind, however, does not justify the common proposition that labor mobility is an important source of knowledge spillovers. Such spillovers (or externalities) are thought to cause underinvestment in private R\&D because workers have incentives to exploit their employers' research results by setting up or joining a competitor.

The aim of this paper is three-fold. First, I want to clarify conceptually how labor mobility can affect $\mathrm{R} \& \mathrm{D}$ investments. I will argue that there are market mechanisms that may internalize the potential externalities involved. Second, I present a framework to test the existence of such market mechanisms, and third I present empirical findings suggesting that these mechanisms actually exist.

The link between labor mobility and knowledge spillovers dates back to Arrow's (1962) article on the public good aspect of knowledge. Arrow writes that "no amount of legal protection can make a thoroughly appropriable commodity of something as intangible as information" and adds that "[m]obility of personnel among firms provides a way of spreading information" (p. 615). Following Arrow's seminal work, a large literature on $\mathrm{R} \& \mathrm{D}$ spillovers has evolved, and economists working in the field have continued to consider labor mobility an important spillover channel. Geroski (1995) expresses what appears to be a common view", writing that "[l] ast but not least, spillovers occur when a researcher paid by one firm to generate new knowledge transfers to another firm (or creates a spin-off firm) without compensating his/her former employer for the full inventory of ideas that travels with him or her."

\footnotetext{
${ }^{1}$ Jaffe (1996) writes that "[k]nowledge spillovers also occur when researchers leave a firm and take a job at another firm". Stephan (1996) writes that "[f]uture work should also focus on the role mobility within the industrial sector plays in facilitating spillovers". Gersbach and Schmutzler (1997) write that "[s]pillovers arise because employees who change jobs take with them all their knowledge, some of which is not specific to their original firm."
} 
That workers do not make such compensations seems obvious since they already possess their employers' knowledge when they decide to leave. The timing of events that Geroski implicitly suggest, however, is misleading. To the extent that research work has a general training element, workers may pay for knowledge as it is accumulated. Whether labor mobility actually reduces appropriability and $\mathrm{R} \& \mathrm{D}$ investments, therefore, is an empirical question. The approach I suggest to answer this question, is to test key implications of models that assume perfect markets. If using standard methodologies ${ }^{2}$ for estimating $R \& D$ spillovers without first considering such a 'benchmark' case, the results of ordinary market exchange may mistakenly be interpreted as R\&D spillovers, and public policy will be misguided ${ }^{3}$.

The basic implications of labor mobility follows from classical human capital theory, cf. Mincer (1958) and Becker $(1962,1964)$. To the extent that workers in R\&D-intensive firms get access to valuable knowledge on the job, they will expect higher wages in the future. When holding jobs that give access to such knowledge, they should therefore be willing to pay for what they learn by accepting wages below their alternative wage. This hypothesis can be tested by using extended Mincer (1974) wage regressions, which is the standard approach in the training literature.

Utilizing a large matched employer-employee data set from the Norwegian machinery and equipment industry, I find that the technical staff in R\&D-intensive firms pay for the knowledge they accumulate on the job through lower wages in the beginning of their career, and that they later earn a return on these implicit investments through higher wages. Scientists and engineers have to accept a wage discount in the order of six percent in their first year after graduation if choosing an 'R\&D intensive' career. This should be considered a conservative estimate, due to a likely ability bias. Towards the end of their career, they receive a wage premium in the order of seven percent. Similar results apply for workers with secondary technical education. When estimating the price paid for learning separately from the return to research experience ${ }^{4}$, I find that having work experience from R\&D intensive firms is associated with higher wages, while the employers current $\mathrm{R} \& \mathrm{D}$ intensity reduce wages for workers with less than 20 years experience. Furthermore, as predicted by human capital theory, the youngest workers appear to invest most heavily in on-the-job learning. These findings suggest that the potential externalities associated with labor mobility, at least to some extent, are internalized in the labor market ${ }^{5}$.

\footnotetext{
${ }^{2}$ Cf. e.g. Jaffe (1986) and Jaffe, Trajtenberg and Henderson (1993).

${ }^{3}$ Zucker, Darby and Armstrong (1998), Klette and Møen (1999) and Klette, Møen and Griliches (2000) elaborate on this point.

${ }^{4}$ I will use 'R\&D experience' as a short term for experience in R\&D intensive firms.

${ }^{5}$ This does not guarantee optimal R\&D investments, however, as credit restrictions or risk averse preferences may reduce worker's willingness to 'co-finance' R\&D. I will return to this in
} 
With respect to mobility patterns, I find a turnover rate of about 20 percent regardless of the firms' R\&D intensity. Excess labor turnover, however, is less in R\&D intensive firms. This effect is particularly pronounced for workers with secondary technical education. If changing employer, workers tend to move to a firm with an R\&D intensity similar to their former employer. Consistent with the lower excess turnover in R\&D intensive firms, research experience from the current employer appears to be more valued than research experience from previous employers.

\section{$2 \quad \mathrm{R} \& \mathrm{D}$ investments and human capital theory}

Research is a learning process, and $R \& D$ investments, therefore, may not only increase a firms' stock of innovations, but also increase the human capital of research workers. In the literature, however, R\&D capital (Griliches; 1973), and human capital (e.g. Becker; 1964) are rarely discussed together. To clarify the relationship between these concepts, I find it useful to classify knowledge along two main dimensions; first to what extent it can be codified, and second to what extent it is diffused throughout the economy.

R\&D capital is knowledge that is not diffused throughout the economy. As long as knowledge is exclusive, those who possess it can earn a monopoly rent and this rent is what motivates investments in $R \& D$. When knowledge is diffused and have become available in the public domain, it will earn a normal rate of return for those who undertake the cost necessary to make it part of their human capital. A research project whose results are perfectly codifiable and not diffused, can be considered pure R\&D capital. It can in principle be protected by patents or other intellectual property right instruments. Hence, labor mobility is not a concern to firms when it comes to appropriating returns in this case.

However, many innovations cannot be properly codified or protected by patents. Appropriability of rents then hinges on the firms' ability to avoid that knowledge leaks out to competitors. Innovations of this type make R\&D spillovers and the problem of underinvestment an important issue. If the intellectual property rights cannot be protected by patents, the R\&D capital of firms is to a large extent embodied in their employees. Such knowledge resembles what Zucker, Darby and Brewer (1998) have called intellectual human capital. A firm that has financed R\&D creating intellectual human capital, cannot prevent its workers from leaving and taking the knowledge with them. Under these circumstances labor mobility is potentially a threat to the firms, and Pakes and Nitzan (1983) analyze the investment incentives of entrepreneurs facing such a situation. Pakes and Nitzan conclude that it is

the concluding section. 
possible to design labor contracts which solve the problem, and that labor mobility therefore does not reduce the appropriability of $R \& D$ investments. I will return to their analysis below.

Over time, as knowledge diffuses, intellectual human capital may either become more codifiable and eventually be learned in schools, or it may become human capital acquired through on-the-job training. The latter kind of human capital also has relevance for an analysis of labor mobility and R\&D investments, as there may be more to learn in firms conducting research because such firms are likely to use the most up-to date technology and frequently change its products and production processes. This training may be valuable to other firms. Furthermore, the distinction between intellectual human capital and on-the-job training does not constitute a clear dichotomy. Many innovations are incremental product and process improvements made at the factory floor, and in the limit they may as well be considered excellent craftsmanship as innovations. A case were different firms offer different opportunities for on-the-job training is analyzed by Rosen (1972).

The rest of this section will outline the theoretical models of Pakes and Nitzan (1983) and Rosen (1972). The main predictions of these models will be discussed and tested in the empirical part of the paper.

The Pakes-Nitzan model The point of departure in Pakes and Nitzan (1983) is Arrow's (1962) reference to labor mobility as a source of R\&D spillover. They argue that even though mobility of scientific personnel will spread knowledge produced in industrial laboratories, it need not be a mechanism which reduces the profitability of research projects and employment in such projects. Both scientists and firms are aware of the fact that working on a research project gives access to valuable information ${ }^{6}$. Once such information is disclosed or developed, scientists, if they are to stay with the firm, will have to receive a wage increase reflecting their new market value. Thus, scientists expect that accepting a research position implies a future wage increase, and consequently they accept an initial wage below their alternative wage.

Next, Pakes and Nitzan notice that if the innovation makes the firm a true monopolist, it will never be profitable for the firm and the scientist to split, since the sum of rents in a duopolistic market will be less than the monopoly rent $^{7}$.

\footnotetext{
${ }^{6}$ Pakes and Nitzan (1983) explicitly model the uncertainty involved in research. This feature of the model does not alter the simple intuition given here, however, because they assume that utility functions are linear in income. Discussing this assumption, they acknowledge that both risk aversion and a lower bound on wages will affect $R \& D$ investments.

${ }^{7}$ Pakes and Nitzan (1983) model only a situation with one entrepreneur and one scientist. If several scientists have equal access to the same critical information, this will complicate the analysis because of potential strategic interaction among the scientists.
} 
Mobility, therefore, should only be observed when it increases the joint profit of the firm and the scientist. This may happen if the firm cannot avoid that other firms get access to valuable information and enter the market ${ }^{8}$. The scientist, by setting up a rival, will then break into profits which otherwise accrue to third parties, and since this profit will be part of the scientists alternative wage in 'period two', it is possible for the firm to extract this rent when setting the 'period one' wage. Another situation which may induce the scientist to join or set up a rival is when the research project create 'spin-offs', some of which are better exploited in a separate firm due to coordination costs. Summarizing the insight of their model, Pakes and Nitzan writes that

mobility of scientific personnel is not, in itself, a source of concern to entrepreneurs. ... $[\mathrm{A}] \mathrm{n}$ optimizing entrepreneur who is free to choose among alternative contracts will always choose one which only induces the scientist to leave and join a rival if the sum of the benefits to the two agents increases as a result of the scientist's leaving. Contracts which specify labor payment in the form of a flat wage and stock option (or other profit sharing agreement) ought to be able to induce close approximation to this behavior.

Balkin and Gomez-Mejia (1985) provide empirical evidence in support of Pakes and Nitzan's prediction. Surveying 105 companies in the Route 128 region around Boston, they find that incentive pay programs are far more common in high-tech firms than in other firms, and that such programs are used for broad levels of technical employees. In addition, key scientists and engineers who help form the companies at an early stage, are given long term stock options.

Rosen's 1972 model The Pakes and Nitzan (1983) model is a two period model of scientists and entrepreneurs, where scientists get access to valuable information, but don't increase their generic productivity. Rosen (1972) models on-the-job learning in a more general human capital context, although one where firms do not have market power. He uses a compensating differential framework, and turns it into "an economic theory of occupational mobility". Rosen thinks of jobs as tied packages of work and learning. Workers sell the services of their skills and simultaneously purchase an opportunity to augment those skills. Some jobs provide more learning

\footnotetext{
${ }^{8}$ Note that spillovers at this point enter the story, but mobility will be a consequence of spillovers, not a source of spillovers. Information can leak out to third parties by reverse engineering, inspection of patent documents, independent research on the same technological problem, etc. Cf. Levin, Klevoric, Nelson and Winter (1987) for a survey of the importance of various information channels. Labor mobility receives a middle score in their study.
} 
opportunities than others. The difference between the maximum market rental of a worker's existing skills and the wage that he or she receives in a given job, is the implicit price the worker pays for learning. Basic human capital theory suggests that a worker's incentive to accumulate human capital is largest at young age. As the worker grows older he or she will have fewer years to collect returns on a given investment, and obviously workers have no incentives to pay for increasing their human capital in the last year before retirement. This imply that the "optimal human capital investment program is implemented by a sequence of job assignments in which workers systematically move and are promoted across jobs that offer successively smaller learning opportunities" (Rosen; 1986).

The point of departure in Rosen's model is a net wage equation

$$
y=\omega H-P(k)
$$

where $y$ is income, $\omega$ is the unit rental price of human capital and $k$ is an index measuring potential learning-by-experience on the job, $k \in[0, \bar{k}] . P(k)$ is an implicit or shadow price function giving the market equalizing wage differential between a job with no learning potential and a job with learning potential $k$. The actual amount of learning by individual $i$ is proportional to $k$ and depends on individual $i$ 's ability, $\alpha_{i} \in[0,1]$ such that

$$
\dot{H}_{i t}=\alpha_{i} k
$$

The workers problem is then to choose a sequence of jobs, $k_{t}$, over his or her lifetime, $T$, to maximize the present value of income, i.e.

$$
\max _{k_{t}} V=\int_{0}^{T}\left[\omega H_{t}-P\left(k_{t}\right)\right] e^{-r t} d t
$$

subject to an initial stock of human capital, $H_{0}$ and $\dot{H}_{i t}=\alpha_{i} k$. Optimization requires that at any time, $t \in[0, T]$,

$$
\frac{P^{\prime}\left(k_{t}\right)}{\alpha_{i}}=\frac{\omega}{r}\left[1-e^{-r(T-t)}\right] .
$$

The expression on the left hand side is the marginal cost of investing in human capital, and the expression on the right hand side is the discounted marginal return. It seems reasonable to assume that $P^{\prime}(k)>0$ and $P^{\prime \prime}(k)>0$, i.e. that the marginal cost of learning is positive and increasing. Given this, optimality requires $k_{t}$ to be largest at the time of entry into the labor market and then to decrease monotonically over time.

Note that the marginal cost of a given real investment in human capital decreases with ability. Hence, workers with higher ability will, all else equal, find it 
profitable to choose jobs with greater learning potential. In the words of Rosen (1972): "Economic incentives induce more 'able' workers to learn more and to accumulate knowledge more rapidly than the less 'able'." This will give rise to a potential selection problem (ability bias) in the empirical application of the model.

\section{Data issues}

The data used in this study comes from three main sources: Governmental administrative records prepared by Statistics Norway ${ }^{9}$, the annual manufacturing census of Statistics Norway ${ }^{10}$, and the biannual R\&D survey of Statistics Norway ${ }^{11}$ supplemented with other surveys of immaterial investments and innovation done by the same agency ${ }^{12}$. The Norwegian data are extraordinary in the sense that the entire working population can be followed over a number of years, and in the sense that extremely rich information is available both about the workers and about their employers. When analyzing labor mobility, the extensive coverage offered by the Norwegian data is a great advantage.

I have chosen to focus on the technical staff ${ }^{13}$ in the machinery and equipment industries as these industries have many high-tech firms and have a fairly complete coverage in the R\&D surveys. The matched employer-employee data set covers the years 1986 to 1995, and I have only included men employed full time in the analysis below. Women do not constitute a large share of the labor stock in these industries, and they are known to have different career patterns and preferences than men.

Even though the data set is rich, I do not have complete information about the workers' careers. Small firms are not necessarily included in the R\&D surveys ${ }^{14}$, and the matching between the different data sources is not perfect. Due to these problems R\&D information is missing for approximately 20 percent of the worker-year

\footnotetext{
${ }^{9}$ Cf. Barth and Dale-Olsen (1999), appendix 2, for some details on the various registers included in the data base. I have taken great care to improve the data quality by checking for consistency across years and across related variables for the same individual. Missing values are imputed where possible.

${ }^{10}$ The census is documented in the series Manufacturing statistics, Official Statistics of Norway NOS C36, Statistics Norway, Oslo. Microdata are available annually from 1972, cf. Halvorsen, Jensen and Foyn (1991) for documentation.

${ }^{11}$ Microdata is available for 1970 , biannually $1975-81$, annually $1981-85$ and biannually $1985-95$. Prior to 1991 the R\&D surveys were conducted by the Royal Norwegian Council for Scientific and Industrial Research. The 1970 survey has been linked to the 1972 manufacturing census.

${ }^{12}$ A survey of immaterial investments was conducted in 1988 covering the years 1986-88 and in 1990 covering the years 1988-90. An innovation survey was conducted in 1993 for the year 1992.

${ }^{13}$ I define the technical staff as workers with secondary technical education and workers with higher technical or scientific education. I refer to the latter group as scientists and engineers.

${ }^{14}$ The R\&D surveys have close to full coverage for firms with more than 20 employees.
} 
observations, and some of the $R \& D$ information present is imputed from previous or later firm observations ${ }^{15}$. On the positive side, however, I do have some information about workers' careers prior to $1986^{16}$, the first year included in the matched data set. I know when the workers started the job they held in 1986, and this can be combined with information about the employers' R\&D investments, in some cases dating as far back as 1970.

Both the (normalized) length of the highest attained education, and the type of education, is recorded in the data. Occupation, however, is not available. Hence, it is not possible to look specifically at researchers, and workers' learning will be proxied by the employers' R\&D intensity. I measure R\&D intensity as R\&D man-years per employee at the three-digit line of business level within firms ${ }^{17}$. I have censored this variable at 0.8 in order to reduce the influence of outliers ${ }^{18}$. If all workers within a firm participate equally in the firm's $R \& D$ efforts, $R \& D$ man-years per employee will measure the share of time that each worker uses to perform R\&D. Since R\&D work obviously is not shared equally among the employees, R\&D intensity is a noisy proxy for what we want to capture. Measurement errors in the R\&D variable, cf. footnote 15 , add to this noise.

Earnings is measured as taxable labor income ${ }^{19}$. The experience measure is real work experience for the youngest cohorts, years since graduation for older cohorts, and potential work experience for cohorts graduating before November $1970^{20}$. Both

\footnotetext{
${ }^{15}$ I have used the following procedure when constructing the R\&D database: First I have linked the $R \& D$ surveys to the manufacturing census. Next, for firms and years not included in the R\&D surveys I have used R\&D information from the surveys of immaterial investments, and from the innovation survey. For firms and years were R\&D information is still missing, I have used survey information about planned $\mathrm{R} \& \mathrm{D}$ one and two years ahead, and information about previous $\mathrm{R} \& \mathrm{D}$. In the final stage, missing $R \& D$ variables were imputed by linear interpolation, and by extrapolating the first observed R\&D intensity backwards in time and the last observed R\&D intensity forward in time, firm by firm. Firms' R\&D investments are known to be stable over time. Imputing missing information when possible, therefore, seems preferable to deleting the observations. 80 percent of the worker-year R\&D variables are from surveys, 5 percent are imputed by interpolation and 15 percent are imputed by extrapolation. 65 percent of the imputed $R \& D$ intensities are zero.

${ }^{16}$ Note, however, that for 16 percent of the observations, the starting date is censored at April 30th 1978. I have used a dummy variable to resolve this problem in regressions where tenure is included.

${ }^{17}$ This means that R\&D intensity is measured at a level 'in between' the firm and the plant. I will use the term firm level $R \& D$ intensity in what follows. If $R \& D$ man-years were not reported, this variable has been imputed based on the firms' R\&D spending.

${ }^{18}$ This affects 0.4 percent of the observations with positive R\&D intensity.

${ }^{19}$ I will often refer to this as the workers' wage.

${ }^{20}$ Potential work experience is age minus schooling minus seven. Real work experience is measured as years since graduation adjusted for pre graduation work experience, part time employment and unemployment within the sample years 1986-1995. When dummy variables are used, they are based on the integer of experience.
} 
experience and tenure are measured in years completed at the beginning of the calendar year.

Information about trimming procedures is given in table A1. In the mobility analysis, all observations with complete information are used, whereas observations with unreliable earnings measures have been excluded from the wage regressions. Trimming based on earnings reduces the sample by 8 percent. Table A2-A6 describe the sample and the main variables.

\section{R\&D investments and labor mobility.}

At first sight, both Rosen (1972) and Pakes and Nitzan (1983) seem to have specific predictions with respect to mobility patterns. A main prediction of Rosen's model is that workers consistently move to jobs with less learning opportunities. In my context, that may imply that workers move from more to less R\&D intensive firms, but as pointed out by Rosen himself, there is heterogeneity with respect to the learning content of jobs not only across, but also within firms. Hence, a clear prediction cannot be deduced.

Pakes and Nitzan (1983) predict that R\&D firms are able to avoid turnover, and thereby spillovers, by sharing the monopoly rent at stake with the workers. In the presence of spin-off innovations or sources of spillovers other than labor mobility, however, they show that mobility actually can be a way of appropriating returns. The model, therefore, like Rosen's, fails to give clear predictions with respect to worker mobility between firms. Furthermore, Pakes and Nitzan (1983) do not consider firm specific knowledge. If firms with different levels of R\&D intensities differ with respect to firm specific human capital, this will also influence the relationship between turnover and R\&D investments ${ }^{21}$.

In lack of strong predictions, empirical mobility patterns cannot be used as a test of the theories. A descriptive analysis of mobility patterns still has interest, however, as it will give insight into the outcome of the different forces at play. The extent to which technically educated workers change employers also illuminate how important labor mobility may be as a source of knowledge diffusion and hence indicate the size of the potential externalities involved.

R\&D investments and worker flows Based on Rosen's model, despite the lack of a clear prediction, one would expect a tendency for workers to move from more to less R\&D intensive firms as a way of reducing their learning in accordance with

\footnotetext{
${ }^{21}$ In the training literature, the effect of training on turnover propensities has been used to assess whether the human capital built up is general or firm specific, cf. e.g. Loewenstein and Spletzer (1999) and Parent (1999).
} 
an optimal human capital investment plan. To investigate this I have calculated a transition matrix of job changes for technical employees between plants with known R\&D intensities. The matrix is reported in table 1 . The most striking result is that workers tend to move between firms with similar levels of R\&D intensity. 65.5 percent of workers leaving a firm that does not conduct R\&D (within the plant's line of business) move to another firm that does not conduct R\&D, even though jobs in such firms account only for 34.6 percent of all jobs. 64.0 percent of workers leaving a firm with R\&D intensity above 0.2 move to another firm with R\&D intensity above 0.2 , although such firms only account for 5.9 percent of all jobs. The pattern is the same for workers leaving firms with intermediate levels of R\&D intensity.

One explanation for the observed stability in R\&D intensity across jobs may be that there is some specificity associated with a given technology level within the industry. As workers grow older, they will then prefer jobs with less learning, within firms at the same level of R\&D intensity as those they have previously worked for. Another explanation may be that workers have preference for work at a given technology level ${ }^{22}$.

R\&D investments and labor turnover As explained above, Pakes and Nitzan (1983) investigate the relationship between R\&D and labor turnover theoretically without reaching a firm conclusion. Table 2 reports labor turnover for technical employees in firms with different levels of $R \& D$ intensity in my sample. The turnover rate is about 20 percent, and does not seem to vary much across firms with different levels of R\&D intensity. What seems most relevant to explore, however, is how R\&D investments affect 'churning', i.e. hires and quits over and above the level necessary to accomplish changes in the number of employees. Excess turnover, a measure of churning $^{23}$, lies between 5 and 10 percent and seems to decrease with R\&D intensity both for workers with secondary technical education and for workers with higher technical or scientific education. A descriptive analysis of excess turnover is not sufficient, however, as a closer inspection of the data reveal that there are significant differences between firms having different levels of $R \& D$ intensity, with respect to other characteristics known to influence turnover such as workers' experience. In order to isolate the effect of $\mathrm{R} \& \mathrm{D}$ on excess turnover, therefore, a regression framework is called for.

Table 3 reports regression results for both a tobit and a maximum likelihood

\footnotetext{
${ }^{22}$ The work of Almeida and Kogut (1996), Stern (1999) and others suggests that scientists and technical personnel have preferences regarding the technological environment that they work in.

${ }^{23}$ Cf. Burgess, Lane and Stevens (1996) and Barth and Dale-Olsen (1999). The excess turnover rate is half the churning rate. I have calculated the excess turnover rate as separations out of jobs that continue divided by the number of continuing jobs.
} 
grouped logit estimator ${ }^{24}$. The estimated relationship is

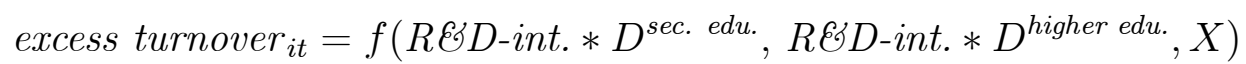

The unit of observation is educational groups within plants. Control variables, $X$, include a quadratic in the educational group number of workers, a quadratic in their average experience, a quadratic in plant age and year dummies ${ }^{25}$.

In the tobit regression I have followed Barth and Dale-Olsen (1999) by excluding small units, limiting the sample to educational groups that consist of at least five workers, cf. footnote 24 . Both the tobit and the grouped logit specification show that excess turnover is lower in R\&D intensive firms. The effect is, however, particularly evident for workers with secondary technical education. One possible explanation is that human capital accumulated by workers with secondary technical education is more firm specific than human capital accumulated by workers with higher technical or scientific education. It may also indicate that the mechanisms related to spinoff innovations and other spillover channels, modelled in Pakes and Nitzan (1983), are relevant in the industries investigated. Workers with higher education would probably be most affected by these mechanisms which increase turnover.

The results in table 3 is consistent with other findings in the empirical literature. Pacelli, Rapiti and Revelli (1998) who estimate the probability of worker firm separations in Italy, find that "more innovative firms cultivate more durable employer-employee relationships", and Greenhalgh and Mavrotas (1996) analyzing the British labor market, find that sectoral R\&D is negatively correlated with lower

${ }^{24}$ Barth and Dale-Olsen (1999) estimate the effect of employers' wage policies on excess turnover, and treat the excess turnover rate as a characteristic of the firm. This leads them to use a tobit estimator. Within such a framework, the observed excess turnover rate must be considered an estimate of a target rate implicit in the firms' personnel policy, and Barth and Dale-Olsen (1999) think in terms of a latent variable censored from below at zero. (One might add to this that the excess turnover rate is also censored from above at one.) As an estimate for the target rate, however, the observed rate is heteroscedastic with a variance proportional to the inverse of the number of employees. Barth and Dale-Olsen (1999) do not explicitly discuss this, but alleviate the problem by limiting the analysis to large firms. Grouped logit eliminates this heteroscedasticity problem. Thinking of the data in this way also changes the perspective from the firm unilaterally deciding an excess turnover rate to individual employer-employee relationships which may or may not continue, depending on both firm and worker characteristics. I find this to be a preferable perspective, as individual employer-employee relationships is the true unit of observation, and it makes sense conceptually to divide observed quits into two groups, those who are replaced, and those who are not replaced. The first type of quits constitute excess turnover while the second type of quits are due to job destruction. If we knew which of the workers who separate that belong to which group, we would no doubt use logit or probit. When we only know the proportion of workers belonging to each group, we can apply grouped logit or probit, cf. Greene (1997, chapter 19.4.3).

${ }^{25} \mathrm{~A}$ complete list is given in the subtext to table 3 . 
mobility. They attribute this only to the presence of firm specific human capital, however, claiming that "the skills acquired [in R\&D intensive sectors] are rather more specific than average".

\section{The effect of R\&D investments on wages}

Pakes and Nitzan (1983) predict lower starting wages and higher wage growth for workers choosing a research career, and Rosen (1972) predicts the same pattern more generally for workers having jobs with a high learning potential. A key assumption behind both models is that workers mainly acquire general human capital on the job. Testing these models, i.e. testing to what extent different firms offer different learning opportunities, and to what extent workers pay for their knowledge accumulation, we would like to estimate equation (1) which is Rosen's point of departure. In principle this is possible. Human capital, $H$, can be decomposed and the price or relative weight of its various components can be estimated using a standard loglinear hedonic wage regression. Furthermore, potential learning-by-experience on the job, $k$, may be proxied by the employer's R\&D intensity as it seems reasonable to assume that workers in 'high-tech', R\&D intensive firms learn more than workers in 'low-tech' firms. However, some problems are immediately evident. Work experience needs to be decomposed according to the training or research content of the jobs that workers have had at different stages of their career, but as explained earlier, complete information about the worker's career histories is not available. Furthermore, it is far from obvious how one can summarize what is known about the workers' experience from different firms into a good measure of human capital. In what follows, I will suggest several solutions to these problems.

A first look at the effect of $R \& D$ on the earnings profile One way to get around the missing career data, is to assume that workers career trajectories are such that the R\&D intensity is constant over their career. Table 1 show that this assumption is valid as an approximation ${ }^{26}$. We can then utilize the structural relationship between $k$ and $H$, given in equation (2) together with the optimal time path for learning investments implicit in (4). Under this assumption the R\&D intensity will at each point of time reveal information both about $k$ and about the component of $H$ representing accumulated R\&D experience. More specifically, the estimated joint effect will give the returns to R\&D experience minus the cost

\footnotetext{
${ }^{26}$ The correlation coefficient between R\&D intensity in year $t$ and $t-1$ is 0.84 . It falls somewhat when the time intervall is increased, but the coefficient is still 0.57 and highly significant between year $t$ and $t$-9. This is the longest observable time span. Note that the correlation coefficients are downward biased due to measurement errors in R\&D intensity.
} 
of learning. Working for a highly R\&D intensive employer should cause a large negative wage premium early in the career, reflecting the implicit price paid for the R\&D experience. At the same time, this experience has not had much time to affect the stock of human capital. As time goes by, workers' willingness to pay for human capital accumulation decrease and approaches zero, but differences in previous R\&D experience will translate into differences in human capital. Workers who are in R\&D intensive firms and have a long $\mathrm{R} \& \mathrm{D}$ intensive career behind them, will therefore have a large positive wage premium reflecting the human capital accumulated.

Table 4 reports the results of simple OLS wage regressions where cross-terms between experience and current $R \& D$ intensity are added to test the hypothesis that employees with a career in R\&D intensive firms have a steeper experienceearnings profile than other workers. Additional control variables included are years of schooling, seven experience dummies ${ }^{27}$, a quadratic in plant number of employees and year dummies. In column 1 and 3 the experience dummies are interacted directly with R\&D intensity while column 2 and 4 report the results of interacting the experience dummies with a dummy which is one if the R\&D intensity is above $0.2^{28}$. An R\&D intensity of 0.2 represents the 97 th percentile for workers with secondary technical education, and the 82th percentile for workers with higher technical or scientific education. The dummy approach is used as an easy way to assess the magnitude of the effect of $R \& D$ intensity on wages. An alternative illustration is given in figure 1, where earnings-experience profiles for workers in firms with no $\mathrm{R} \& \mathrm{D}$ and in firms with $\mathrm{R} \& \mathrm{D}$ intensity 0.2 is graphed, based on a specification with a quartic in experience interacted with a quadratic in R\&D intensity.

The results support the main theoretical prediction of Pakes and Nitzan (1983) and Rosen (1972). Early in the career both workers with secondary technical education and scientists and engineers accept a significant wage discount when working for R\&D-intensive firms, but over time this discount is changed into a significant wage premium. The pattern strongly suggests that $\mathrm{R} \& \mathrm{D}$-investments of firms translate into general human capital, and that workers both pay and get paid for the knowledge they accumulate.

It is evident from table 4, columns 2 and 4, using the dummy variable approach,

\footnotetext{
${ }^{27}$ I have chosen to use experience dummies rather than a higher order polynomial in the main specification because the tabulation of cross terms between R\&D intensity and a higher order polynomial is difficult to interpret. A polynomial in experience interacted with R\&D intensity also imply a stronger restriction on the effect of $R \& D$ over the career.

${ }^{28}$ In these regressions, workers in firms with medium R\&D intensity have been excluded. Medium $\mathrm{R} \& \mathrm{D}$ intensity is defined as an R\&D intensity between 0.05 and 0.2 . The exclusion is done to facilitate a sharper comparison between workers in firms with high and low R\&D intensity. The results are robust to including workers in firms with medium R\&D intensity, and to using the 90th percentile for each group as a cutoff point instead of $0.2 \mathrm{R} \& \mathrm{D}$ intensity.
} 
that the discounts as well as the premia are of economic significance. Scientists and engineers working in firms with an $R \& D$ intensity above 0.2 , have on average 6.1 percent lower wages in their first year than scientists and engineers in firms with R\&D intensity below 0.05 . Scientists and engineers with more than 35 year experience and working in a firm with $R \& D$ intensity above 0.2 , have wages that on average are 6.8 percent above the wages of scientists and engineers with similar experience in firms with $\mathrm{R} \& \mathrm{D}$ intensity below 0.05 . The magnitudes of the discounts and premia are similar for workers with secondary technical education in R\&D intensive firms. They have a 5.5 percent wage discount in the beginning of their career, and an 8.6 percent premium in the end of their career.

One way to check the plausibility of the coefficients is to calculate the internal rate of return to choosing an $\mathrm{R} \& \mathrm{D}$ intensive career. For a worker with secondary technical education, the internal rate of return is 5.7 percent, and for workers with higher technical or scientific education it is 3.6 percent $^{29}$. These numbers should be considered rough estimates, but they are in a reasonable range.

Estimates based on earnings growth One major obstacle to identifying compensating differentials, whether associated with training or other job amenities, has been the potential correlation between job amenities and unobserved individual characteristics. In Rosen's model, an ability bias arises because highly talented workers have a lower cost of learning, and absorb more knowledge in a job with a large potential for learning, than less talented workers ${ }^{30}$. This imply a tendency for talented workers to self-select into R\&D intensive firms, causing the wage discount in the beginning of the career to be underestimated, and the wage premium in the end of the career to be overestimated ${ }^{31}$.

Another potential bias in table 4 arises from workers switching between employment in 'high-tech' and 'low-tech' firms. Although table 1 indicates that this kind of behavior is not very common, it clearly does happen. A bias then arises because the regressions in table 4 assume that we can compare experienced workers in $\mathrm{R} \& \mathrm{D}$ intensive firms to experienced workers in less $R \& D$ intensive firms, and learn how

\footnotetext{
${ }^{29}$ The calculation is based on the regressions in table 5, column 2 and 4 . I assume that the workers are employed in a firm with 100 employees, and that the business cycle is as it were in 1995. Workers with secondary education are assumed to have 12 years of schooling and work for 45 years. Workers with higher education are assumed to have 15 years of schooling and work for 42 years.

${ }^{30} \mathrm{Cf}$. Autor (2000) for a model with the same feature.

${ }^{31} \mathrm{It}$ is in this respect interesting to note that the estimated coefficients on R\&D-intensity become smaller (more negative) if the share of scientists with post graduate degrees at the plant is included in the regression, despite this variable being strongly correlated with $R \& D$ intensity. One possible explanation is that the share of post graduate scientists also is correlated with unobserved worker ability. This would be consistent with the 'O-ring theory' of Kremer (1993).
} 
much more human capital is accumulated in R\&D intensive firms. Workers who transfer out of R\&D intensive firms, however, will increase the wage level of the 'comparison group' in the less R\&D intensive firms, and cause a downward bias on the estimated gain from working in $R \& D$ intensive firms. In the same way, workers who transfer from firms that do not invest much in R\&D to firms that do, have less human capital than those who have been in R\&D intensive firms for their entire career. Hence, they will reduce the average wage level in R\&D intensive firms and add to the bias. The result is that the wage premia associated with the last periods of a 'high tech career' is underestimated, i.e. we will underestimate the steepness of the experience earnings profile.

A simple way to avoid the potential ability and 'switching' bias, is to estimate the wage equation in first differences, i.e. investigate how firms' R\&D intensity affect wage growth directly. This is done in table 5. The drawback of this specification is that we do not learn about the effect of R\&D on the wage level ${ }^{32}$. Given that ability is expected to bias results against finding support for the hypothesis that workers pay for R\&D experience, however, this is not a serious problem.

The broad picture emerging from the upper part of table 5 is that workers with technical or scientific education in R\&D-intensive firms who do not change employer, have higher wage growth throughout their career ${ }^{33}$. This is consistent with the previous finding that $\mathrm{R} \& \mathrm{D}$ translates into human capital that workers earn a return $\mathrm{on}^{34}$. Wage growth also appears to level off towards the end of the career, consistent with workers having less incentive to accumulate human capital when getting closer to the retirement age.

Since the correlation between firms' R\&D intensity and workers' learning investments is expected to be strongest for young workers, it should be possible to observe changes in 'payment' associated with transitions between firms with different R\&D intensities. Moving from an R\&D-intensive firm to a less R\&D-intensive firm early in the career should induce a wage increase, and transitions the opposite way should induce a wage decrease. Both types of moves will contribute to a negative relation-

\footnotetext{
${ }^{32}$ The wage level is identified if using a fixed effects specification, but such a specification does not perform well. This may be due to its more restrictive assumption regarding the dynamics of unobserved worker characteristics.

${ }^{33}$ Note, however, that wage growth for workers with secondary technical education is negatively correlated with the employers' R\&D intensity in the first two years of the career. This is also evident in table 4, column 1. It may reflect that it takes some time to 'absorb' the complexity of $R \& D$ intensive firms, or that workers due to imperfect information about the quality of the training, are unwilling to pay the full cost of the training at once, but that firms are able to extract more through lower wage growth during the very first years of the workers' career.

${ }^{34}$ Cash flow before wage payments per worker, is included to control for the rent sharing effect of successful innovations found by van Reenen (1996). Such a rent sharing effect is present in the data, but it does not dominate the effect of $R \& D$.
} 
ship between wage growth and change in $R \& D$ intensity. For old workers, a change in $R \& D$ intensity should not affect wages as much, since they are not expected to invest much in human capital. The estimated coefficients do not fully confirm these hypotheses. For old workers, the coefficients are small and not very significant as expected, and for young workers with secondary technical education the coefficient is negative and highly significant, but for young scientists and engineers the coefficient is positive and significant. A problem with the estimates, however, is that mobility cannot be considered exogenous with respect to wages.

Estimating the price of learning and the return to $R \& D$ experience separately Table 4 utilize cross sectional information only, and estimates in one coefficient the return to previous $\mathrm{R} \& \mathrm{D}$ experience minus the price paid for current learning opportunities. Utilizing the longitudinal dimension of the data set it is possible to specify these two components separately. The learning opportunity that a worker faces depends only on current R\&D intensity, while average R\&D intensity in previous years reveal information about the workers' $R \& D$ experience. Note, however, that the stability in $\mathrm{R} \& \mathrm{D}$ intensity over the workers careers, evident in table 1, makes current and previous R\&D intensities somewhat collinear. A high level of precision can therefore not be expected when including both variables.

Table 6, column 2 and 4, reports the results of interacting current R\&D intensity and the average of previously observed $R \& D$ intensities separately with experience dummies. The first thing to notice is that the coefficients on the average of previously observed $R \& D$ intensities, i.e. the return to $R \& D$ experience, are mostly positive, while the coefficients on current R\&D intensity, i.e. the implicit price paid for learning opportunities, are mostly negative. Note also that current R\&D intensity has a more negative impact when previous $R \& D$ experience is included, cf. column 1 and 3 .

The price paid for learning decreases over time as predicted by theory, but the data do not bring out the expected wage increase over time that should be associated with R\&D experience. Furthermore, the coefficients on current R\&D, i.e. learning, does not go to zero, but becomes positive late in the career. These two features seem connected. The employer's current R\&D intensity appears to be a better proxy for old workers' human capital than the average of previously observed R\&D intensities. This could be due to some selection process where workers whose technological experience has become obsolete, move out of or are displaced from R\&D intensive firms.

In order to asses the importance of learning for the industry on an aggregate level, I have summarized the estimated wage discount for all R\&D firms. This sum amounts to 0.7 percent of the total wage bill for technical personnel in all $R \& D$ 
performing firms and 2.6 percent of industry R\&D investments. Looking only at firms with $R \& D$ intensity above 0.2 , the wage discount represent 3.0 percent of their total wage bill and 2.5 percent of their R\&D investments. These numbers are not very big, but nor are they negligible.

The value of $R \& D$ experience from the current employer vs. previous employers Lengermann (1996) and Loewenstein and Spletzer (1998, 1999) who study the effect of formal on-the-job training, find that the return to training received from previous employers exceed the return to training received from the current employer. Loewenstein and Spletzer argue that this may reflect that employers extract some returns to general training, and that workers do not realize the full returns until they change jobs. If something similar applies to the value of experience from R\&D intensive firms, it would imply that the potential R\&D spillovers involved when workers in R\&D intensive firms change employers, is only partially internalized in the labor market. In order to investigate this possibility, I have for each employee where sufficient career information is present, calculated the average observed R\&D intensity in previous years when working for the current employer and the average observed R\&D intensity in years working for previous employers.

With a smaller sample size and three R\&D measures, an extension of the specification with experience dummies interacted with R\&D-intensities, used in table 4 and 6 , is not feasible. It is necessary to put more restrictions on the specification and I have chosen to approximate the price paid for learning opportunities with current $R \& D$ intensity and its interaction with years of overall work experience. $R \& D$ experience built up with the current employer is proxied with the average observed $R \& D$ intensity in previous years working for this employer times years of tenure with this employer. R\&D experience built up with previous employers is proxied with the average observed R\&D intensity while working for previous employers times years of experience prior to the current employment relationship. These measures, resembling sums of $R \& D$ intensities, are consistent with equation (2).

Table 7, column 1 and 3 reports the results. Column 2 and 4 report a slightly less restrictive specification where non-linear interactions with experience and tenure is allowed. All regressions confirm the previous finding that current R\&D intensity have a significantly negative impact on wages early in the career. The positive cross-term with experience also confirm that this negative impact, interpreted to be the price paid for learning opportunities, diminishes over time. With respect to the $R \& D$ experience built up over the career, both $R \& D$ experience from the current employer and $R \& D$ experience from previous employers have a positive and significant impact on wages. R\&D experience from the current employer, however, seems to be more highly valued. Unfortunately, this result is more suggestive than 
conclusive. In order to construct the variables needed, all years working with the current employer must be included in the sample, while information about previous employers can be less complete. Hence, the average R\&D intensity in years working for previous employers is measured with greater error than average $R \& D$ intensity in years working for the current employer, and coefficients on variables involving the former measure will therefore be more biased towards zero ${ }^{35}$. In addition, the coefficient on R\&D experience with the current employer could be upward biased. This would happen if recent R\&D experience show that knowledge accumulated earlier in the career has not become obsolete. The results for old workers in table 6 indicate that this may be the case.

Robustness and econometric issues A number of alternative specifications have been tried to asses the robustness of the results ${ }^{36}$. In one specification, more than 30 additional control variables were included, such as proxies for hours worked ${ }^{37}$, the capital to labor ratio, the Herfindal index, the market share of the firm, the union density $^{38}$ and four-digit industry dummies. This did not change the quantitative re-

\footnotetext{
${ }^{35}$ If the sample is restricted to workers whose complete career is known, the return to $R \& D$ experience from previous employers appears to be above the return to $R \& D$ experience from the current employer for workers with higher education, while both coefficients become insignificant for workers with secondary education. For these workers the coefficient on previous $R \& D$ experience even has a negative sign.

${ }^{36}$ In addition to trying out different specifications within the sample of workers with technical education, I have also run the basic regressions on workers with non-technical education. The effect of $R \& D$ experience on workers with non-technical secondary and higher education resembles the effect on workers with technical education in that they seem to have a steeper experience-earnings profile if working in R\&D-intensive firms. The results are fairly strong for workers with secondary non-technical education, but less evident for workers with higher non-technical education. It is not clear why these workers should be affected by the R\&D-intensity of their employers, but several explanations are possible. First, R\&D intensive firms may be advanced along many dimensions, and hence offer valuable work experience also to the non-technical staff. Second, R\&D intensive firms also appear to be intensive in formal training. In years where the dataset includes measures of both R\&D investments and formal training, these measures are significantly, positively correlated. Third, it is possible that not only the technical staff, but also administrative managers in R\&D intensive firms have access to sensitive technological information. Then the Pakes and Nitzan (1983) model applies to this group as well as to the technical employees, and it is in any case conceivable that R\&D intensive firms to a larger extent than other firms use stock options and similar compensation schemes for their managers, e.g. due to cash constraints. Finally, the Norwegian economy is strongly unionized. Unions often demand similar earnings plans for all employees in a firm.

${ }^{37}$ The following measures are available: Average hours per week worked at the plant, number of part time jobs and number of months unemployed.

${ }^{38}$ The union density is only available after 1990. In 1990 and before, I have used the 1991 value, since union density as a firm characteristic is fairly stable over time.
} 
sults. The results are also robust to including firm size, years of education and union density in interaction with experience. Dividing the sample into different time periods, however, reveals that the effect of $\mathrm{R} \& \mathrm{D}$ on the wage-experience profile is more pronounced in the 1980s than in the 1990s. This may be related to the severe recession in the Norwegian economy starting in the late 1980s, causing a restructuring of, and a decline in, some of the most innovative subindustries.

All regressions reported in tables 4, 6 and 7 allow for correlated error terms across observations of the same individual in different years. However, one could also argue that error terms for workers belonging to the same firm may be correlated. Allowing for such correlations when computing the standard error of the estimated coefficients, reduce their significance, but the qualitative results are even robust to including firm specific fixed effects in the regressions.

A comparison with the training literature Before concluding it may be worthwhile to compare the overall results to similar analyses of 'on-the-job training' in the labor literature. Although this paper, as far as I know, is the first to look at the effect of $\mathrm{R} \& \mathrm{D}$ on wages, there exists a large literature on the effect of formal training. In this literature, a number of authors have found training to be correlated with wage growth, but finding support for a negative effect on starting wages such as human capital theory predicts, is unusual, cf. e.g. Barron, Black and Loewenstein (1989), Lynch (1992) or Barron, Berger and Black (1999) ${ }^{39}$. Common interpretations are that workers do not pay for general training, or that the implicit price is masked by a positive ability bias. In this perspective, the strong negative effect of $\mathrm{R} \& \mathrm{D}$ on starting wages present in this sample, is remarkable. It suggests that firms' technology levels are more important to wages than formal on-the-job training. One explanation for this could be that while most formal training is short term, working in a technologically challenging environment affects human capital accumulation for the entire duration of a job.

\section{Concluding remarks}

Labor mobility is often considered to be an important source of knowledge externalities, making it difficult for firms to appropriate returns to R\&D investments. Pakes and Nitzan (1983), however, analyze the problem formally, and find that labor turnover should not be a problem for R\&D firms. Both scientists and firms

\footnotetext{
${ }^{39}$ One exception is Autor (2000). Studying temporary help firms, he finds that "[w]ages are lower at firms offering training by a modest, but statistically significant magnitude". Lynch (1992) find a negative effect of uncompleted training for workers with less than high school education, but not for workers with a high school degree or some college education.
} 
are aware of the fact that working on a research project gives access to valuable information. Once such information is disclosed or developed, scientists, if they are to stay with the firm, will have to receive a wage increase reflecting their new market value. Thus, scientists expect that accepting a research position implies a future wage increase, and consequently they can accept an initial wage below their alternative wage, without experiencing a welfare loss.

Research firms are likely to use the most up-to date technology and frequently change its products and production processes. Because of this, one would think that even workers who don't have direct access to the results of the R\&D projects, learn more in these firms. Rosen (1972) provides a model where different firms offer different opportunities for on-the-job learning, and derive implications with respect to wages that closely resemble those of Pakes and Nitzan (1983). Rosen thinks of jobs as tied packages of work and learning. Workers sell the services of their skills and simultaneously purchase an opportunity to augment those skills.

I have argued in this paper that inter-firm transfers of $R \& D$-results embodied in people, should be analyzed within a human capital framework similar to the models of Pakes and Nitzan (1983) and Rosen (1972). Testing such a framework using matched employer-employee data from the Norwegian machinery and equipment industries, I find that the technical staff in R\&D-intensive firms indeed pays for the knowledge they accumulate on the job through lower wages in the beginning of their career. Later in the career they earn a return on these implicit investments through higher wages. This suggests that potential externalities associated with labor mobility, at least to some extent, are internalized in the labor market ${ }^{40}$.

Determining whether workers pay for the full value of the knowledge they accumulate in R\&D intensive firms, however, is difficult, and beyond the scope of this paper. Information asymmetries and other barriers to mobility may enhance the firms ability to appropriate rents, but at the same time reduce workers' incentives to pay for knowledge accumulation. Under such circumstances it is conceivable that labor mobility creates some knowledge spillovers ${ }^{41}$. A complete welfare analysis must

\footnotetext{
${ }^{40}$ The only related finding I know of in the literature is Zucker, Darby and Armstrong (1998) who in an academic setting, claim that "competitive university salaries are lower, other things equal, in areas where faculty expect the possibility of receiving substantial outside income or wealth as a result of skills developed doing research at the university."

${ }^{41}$ Cf. Acemoglu and Pischke (1999) although these authors do not write with reference to R\&D investments. A particularly important kind of imperfection may be distortions in the wage structure which makes a wedge between wages and marginal productivity increase with the workers' human capital. Firms then have an incentive to invest in R\&D producing general human capital because they get a share of the return. A simple mechanism which could cause such wage compression, is that firms receive a fraction of the productivity of the workers as profit due to matching, search costs or other sorts of labor market friction. If the employer receives a fraction of the workers' productivity, the employers level of profit will increase with the workers' productivity and therefore
} 
also incorporate that, even if workers pay for all the knowledge they accumulate, this 'solution' to the spillover problem does not guarantee optimal R\&D investments. If workers co-finance R\&D through lower wages, and if the value of the knowledge they accumulate depend on the outcome of the $R \& D$ project, they become exposed to the risk associated with the project. Risk aversion among workers may then become a new source of distortion since human capital investments cannot be diversified ${ }^{42}$. Liquidity constraints making workers unwilling to trade off current wage for future wage on a large scale, may also create problems.

\section{References}

Acemoglu, D. and Pischke, J.-S. (1999). Beyond Becker: Training in imperfect labor markets, Economic Journal 109: F112-F142.

Almeida, P. and Kogut, B. (1996). Thechnology and geography: The localization of knowledge and the mobility of patent holders. Working Paper, The Huntsman Center for Global Competition and Innovation, Wharton School, University of Pennsylvania.

Arrow, K. J. (1962). Economic welfare and the allocation of resources for invention, in R. R. Nelson (ed.), The Rate and Direction of Inventive Activity: Economic and Social Factors, Vol. 13 of NBER Special Conference Series, Princeton University Press, New Jersey, pp. 609-625.

Autor, D. H. (2000). Why do temporary help firms provide free general skills training. NBER Working Paper No. 7637.

with their human capital. Another possible mechanism is complementarity between firm specific and general human capital. In this case, the alternative wage for the scientist will increase less than his or her productivity as he or she receives training. Mechanisms which induce employers to pay for general human capital accumulation, create a positive externality to the worker's future employer if the worker decides to quit or if the firm goes out of business. If labor mobility does create some knowledge spillovers, multiple equilibria may be possible. One mechanism that may produce such a result is complementarity between firms' own research investments and the faster knowledge diffusion and improved matching associated with a high-mobility equilibrium. Cf. e.g. Cohen and Levinthal (1989) for an analysis which stress the importance of complementarities between spillovers and firm's own R\&D investments. A tolerant attitude towards movement of personnel, reported to be present e.g. in Silicon Valley (Saxenian; 1994), could then promote R\&D investments and growth, whereas a situation where firms make labor mobility costly could produce an equilibrium with low $R \& D$ investments and growth. The latter result would be due to low quality matches combined with a low inflow of new ideas, and despite the fact that lower probability of quits, all else equal, improves the incentives to invest in R\&D.

${ }^{42} \mathrm{Cf}$. footnote 6 . 
Balkin, D. B. and Gomez-Mejia, L. R. (1985). Compensation practices in hightechnology industries, Personnel Administrator (June): 111-123.

Barron, J. M., Berger, M. C. and Black, D. A. (1999). Do workers pay for on-the-job training?, Journal of Human Resources 34(2): 235-252.

Barron, J. M., Black, D. A. and Loewenstein, M. A. (1989). Job matching and on-the-job training, Journal of Labor Economics 7(1): 1-19.

Barth, E. and Dale-Olsen, H. (1999). The employer's wage policy and worker turnover, in J. C. Haltiwanger, J. I. Lane, J. R. Spletzer, J. J. M. Theeuwes and K. R. Troske (eds), The Creation and Analysis of Employer-Employee Data, Contributions to Economic Analysis 241, North Holland, Amsterdam, pp. 285312 .

Becker, G. S. (1962). Investment in human beings, Journal of Political Economy pp. 9-49.

Becker, G. S. (1964). Human Capital, Columbia University Press, New York. [Third Edition by the University of Chicago Pess 1993].

Bhide, A. (1994). How entrepreneurs craft strategies that work, Harvard Business Review 72: 150-161.

Burgess, S., Lane, J. and Stevens, D. (1996). Job flows and workers flows: Issues and evidence from a panel of US firms, in R. Schettkat (ed.), The Flow Analysis of Labour Markets, Vol. 3 of Studies in the Modern World Economy, Routledge, London and New York, pp. 96-114.

Cohen, W. M. and Levinthal, D. A. (1989). Innovation and learning: The two faces of R\&D, Economic Journal 99: 569-596.

Geroski, P. A. (1995). Do spillovers undermine the insentive to innovate?, in S. Dowrick (ed.), Economic Approaches to Innovation, Edwar Elgar, Aldershot, UK, pp. 76-97.

Gersbach, H. and Schmutzler, A. (1997). Endogenous spillovers, the market for human capital, and incentives for innovation. Discussion Papers No. 248, Universität Heidelberg.

Greene, W. H. (1997). Econometric Analysis, Third Edition, Prentice Hall, New Jersey.

Greenhalgh, C. and Mavrotas, G. (1996). Job training, new technology and labour turnover, British Journal of Industrial Relations 34(1): 131-150.

Griliches, Z. (1973). Research expenditures and growth accounting, in B. R. Williams (ed.), Science and Technology in Economic Growth, MacMillian, Lon- 
don, pp. 59-95.

Halvorsen, R., Jensen, R. and Foyn, F. (1991). Dokumentasjon av Industristatistikkens Tidsseriebase. Mimeo, Statistics Norway.

Jackson, T. (1997). Inside Intel: Andrew Grove and the Rise of the World's Most Powerful Chip Company, Dutton Books.

Jaffe, A. (1986). Technological opportunity and spillovers from R\&D, American Economic Review 76: 984-1001.

Jaffe, A. (1996). Economic analysis of research spillovers: Implications for the advanced technology program. National Institute of Standards and Technology, Report GCR 97-708.

Jaffe, A. B., Trajtenberg, M. and Henderson, R. (1993). Geographic localization of knowledge spillovers as evidenced by patent citations, Quarterly Journal of Economics 108: 577-598.

Klette, T. J. and Møen, J. (1999). From growth theory to technology policy - coordination problems in theory and practice, Nordic Journal of Political Economy 25(1): 53-74.

Klette, T. J., Møen, J. and Griliches, Z. (2000). Do subsidies to commercial R\&D reduce market failure? Microeconometric evaluation studies, Research Policy 29(45): 471-495.

Kremer, M. (1993). The O-ring theory of economic development, Quarterly Journal of Economics 108: 551-575.

Lengermann, P. A. (1996). How long do the benefits of training last? Evidence of long term effects across current and previous employers, education levels, test scores, and occupations. Working Paper 96-18, CAHRS, Cornell University.

Levin, R. C., Klevoric, A. K., Nelson, R. R. and Winter, S. G. (1987). Appropriating the returns from industrial research and development, Brookings Papers on Economic Activity, Microeconomics pp. 783-831.

Loewenstein, M. A. and Spletzer, J. R. (1998). Dividing the costs and returns to general training, Journal of Labor Economics 16(1): 142-171.

Loewenstein, M. A. and Spletzer, J. R. (1999). General and specific training, evidence and implications, Journal of Human Resources 34(4): 710-733.

Lynch, L. M. (1992). Private sector training and the earnings of young workers, American Economic Review 82(1): 299-312.

Mincer, J. (1958). Investment in human capital and personal income distribution, 
Journal of Political Economy 66: 281-302.

Mincer, J. (1974). Schooling, Experience and Earnings, Columbia University Press, New York.

Pacelli, L., Rapiti, F. and Revelli, R. (1998). Employment and mobility of workers in industries with different intensity of innovastion: Evidence on Italy from a panel of workers and firms, Economics of Innovation and New Technologies 5: 273-300.

Pakes, A. and Nitzan, S. (1983). Optimum contracts for research personnel, research employment, and the establishment of 'rival' enterprises, Journal of Labor Economics 1: 345-365.

Parent, D. (1999). Wages and mobility: The impact of employer-provided training, Journal of Labor Economics 17(2): 298-317.

Rosen, S. (1972). Learning and experience in the labor market, Journal of Human Resources 7: 326-342.

Rosen, S. (1986). The theory of equalizing differences, in O. Ashenfelter and R. Layard (eds), Handbook of Labor Economics, Vol. I, North-Holland, Amsterdam, chapter 12, pp. 641-692.

Saxenian, A. (1994). Regional Advantage: Culture Competition Between Route 128 and Silicon Valley, Harvard University Press, Cambridge, Mass.

Stephan, P. (1996). The economics of science, Journal of Economic Literature 34(3): 1199-1235.

Stern, S. (1999). Do scientists pay to be scientists? NBER Working Paper No. 7410.

van Reenen, J. (1996). The creation and capture of rents: Wages and innovation in a panel of UK companies, Quarterly Journal of Economics 111: 195-226.

Zucker, L. G., Darby, M. R. and Armstrong, J. (1998). Geographically localized knowledge: Spillovers or markets?, Economic Inquirey 36: 65-86.

Zucker, L. G., Darby, M. R. and Brewer, M. B. (1998). Intellectual human capital and the birth of US biotechnology enterprises, American Economic Review 88: $290-306$. 


\section{Figure 1. Estimated earnings-experience profiles}

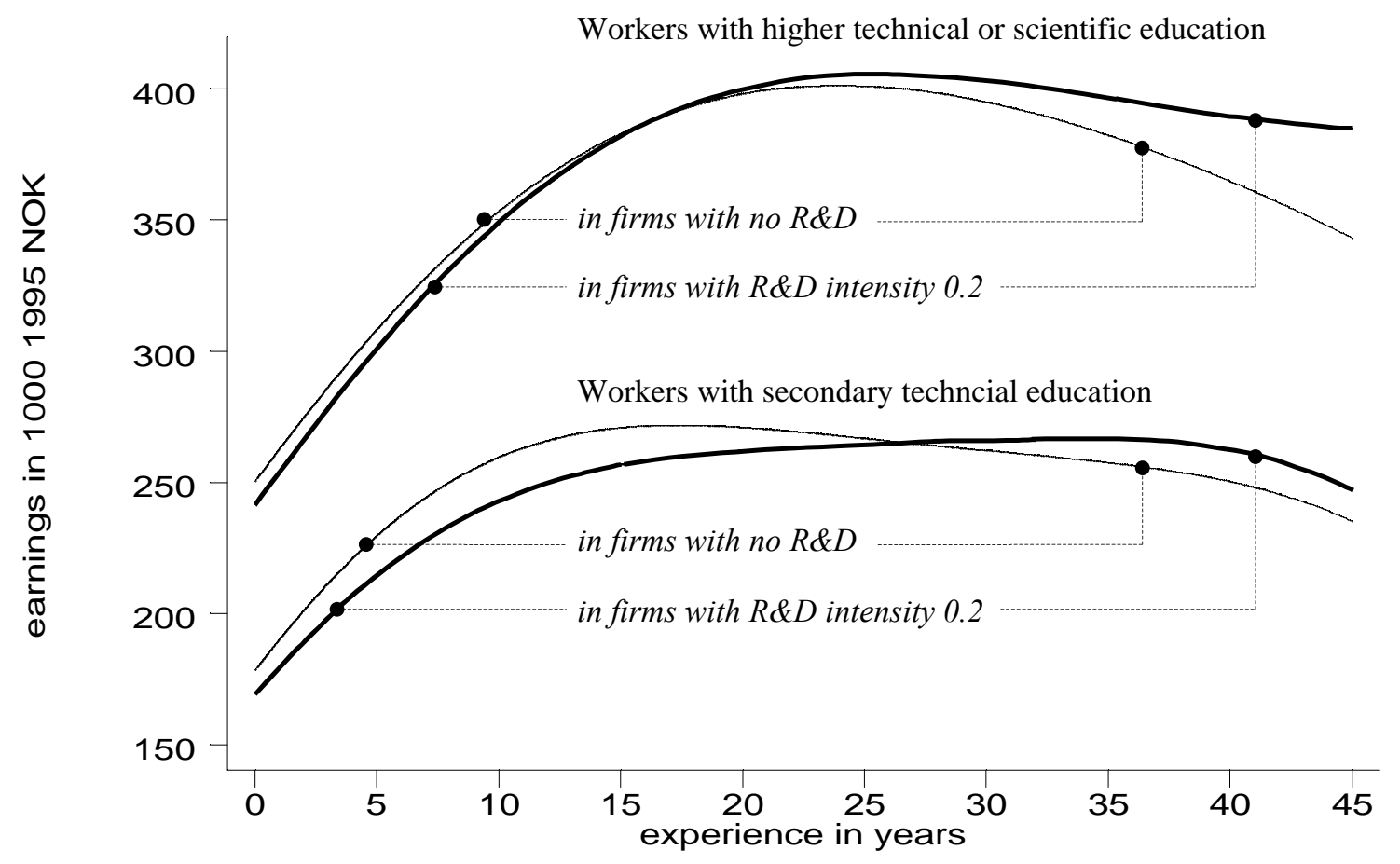

The graphs are based on regressions similar to those in table 4, column (1) and (3) except that experience dummies interacted with $R \& D$ intensity is exchanged with a quartic in experience interacted with a quadratic in $R \& D$ intensity. $R \& D$ intensity is measured as R\&D man-years per employee at the three-digit line of business level within firms. The sample consists of men with technical or scientific education employed full time in the machinery and equipment industry in Norway 1986-1995. The graphs for workers with higher education are based on 15 years of education and a firm with 100 employees. The graphs for workers with secondary education are based on 12 years of education and a firm with 100 employees. Business cycle conditions are assumed to be like 1995. 


\section{Table 1. Worker mobility between plants with known R\&D intensity}

\begin{tabular}{lrrrrr}
\hline \hline & $\begin{array}{c}\text { with } \\
\text { no R\&D }\end{array}$ & $\begin{array}{c}\text { with } \\
\text { R\&D- } \\
\text { intensity } \\
\in\langle 0, .05]\end{array}$ & $\begin{array}{c}\text { with } \\
\text { R\&D- } \\
\text { intensity } \\
\in<.05, .2]\end{array}$ & $\begin{array}{c}\text { with } \\
\text { R\&D- } \\
\text { intensity } \\
>.2\end{array}$ & $\begin{array}{c}\text { Total } \\
\text { number } \\
\text { of sepa- } \\
\text { rations }\end{array}$ \\
\hline left a non R\&D-plant and joined a plant & 65.5 & 27.3 & 5.7 & 1.5 & 3168 \\
left a plant with R\&D-intensity $\in\langle 0, .05]$ and joined a plant & 27.8 & 61.1 & 8.9 & 2.2 & 3330 \\
left a plant with R\&D-intensity $\in\langle .05, .2]$ and joined a plant & 11.9 & 42.6 & 40.4 & 5.1 & 2841 \\
left a plant with R\&D-intensity $>.2$ and joined a plant & 12.9 & 9.3 & 13.9 & 64.0 & 497 \\
\hline \hline percentage of jobs in plants & 34.6 & 42.3 & 17.2 & 5.9 &
\end{tabular}

The numbers are percentage shares of total separations from each category of plants and sum to 100 horizontally. The sample consists of men with technical or scientific education employed full time in the machinery and equipment industry in Norway 1986-1995 at a plant where the R\&D-intensity is known. Transitions out of the sample have been excluded. $R \& D$ intensity is measured as $R \& D$ man-years per employee at the three-digit line of business level within firms. 
Table 2. Labor turnover by education and R\&D intensity

\begin{tabular}{|c|c|c|c|}
\hline & $\begin{array}{l}\text { Turnover } \\
\text { rate }\end{array}$ & $\begin{array}{l}\text { Excess } \\
\text { turnover } \\
\text { rate } \\
\end{array}$ & $\begin{array}{c}\text { Number of } \\
\text { job-year } \\
\text { observations }\end{array}$ \\
\hline \multicolumn{4}{|c|}{ Secondary technically educated in a plant } \\
\hline with no R\&D & .194 & .095 & 110091 \\
\hline with R\&D-intensity $\in\langle 0, .05]$ & .210 & .091 & 84886 \\
\hline with $R \& D$-intensity $\in\langle .05, .2]$ & .211 & .072 & 37280 \\
\hline with R\&D-intensity $>0.2$ & .208 & .059 & 7246 \\
\hline \multicolumn{4}{|c|}{ Higher technically or scientifically educated in a plant } \\
\hline with no R\&D & .191 & .074 & 14806 \\
\hline with $R \& D$-intensity $\in\langle 0, .05]$ & .210 & .075 & 20444 \\
\hline with $\mathrm{R} \& \mathrm{D}$-intensity $\in\langle .05, .2]$ & .211 & .071 & 20782 \\
\hline with R\&D-intensity >0.2 & .216 & .065 & 11838 \\
\hline
\end{tabular}

The turnover rate is separations in year $t$ as a share of employment in year $t$. The excess turnover rate is separations out of jobs that continue as a share of continuing jobs. $R \& D$ intensity is measured as R\&D man-years per employee at the threedigit line of business level within firms. The sample consists of men with technical or scientific education employed full time in the machinery and equipment industry in Norway 1986-1995.

\section{Table 3. The effect of R\&D intensity on excess turnover}

\begin{tabular}{|c|c|c|}
\hline \multicolumn{3}{|l|}{ R\&D-intensity } \\
\hline * secondary technical education & $-.119 * * *$ & $-2.041 * * *$ \\
\hline \multirow{3}{*}{ * higher technical or scientific education } & $(.030)$ & $(.416)$ \\
\hline & -.042 & $-.721^{*}$ \\
\hline & $(.030)$ & $(.376)$ \\
\hline Estimator & Tobit & Grouped logit \\
\hline Sample size & 6904 & 266173 \\
\hline Pseudo R-squared & .42 & .01 \\
\hline
\end{tabular}

The dependent variable is the excess turnover rate within plant educational groups. The excess turnover rate is separations out of jobs that continue as a share of continuing jobs. Control variables included in the regressions, but not reported are a dummy for higher technical or scientific education, plant job destruction rate, plant job creation rate, a quadratic in the educational group number of workers, a quadratic in their average experience, a quadratic in plant age and year dummies. The sample sizes in the tobit regressions refer to the number of within plant educational groups. Educational groups with less than five workers have been excluded from the tobit regressions due to the turnover estimates being uncertain when based on few workers. The sample sizes in the grouped logit regressions refer to the number of workers. Standard errors are given in parentheses. In the grouped logit regressions, the standard errors are adjusted for heteroscedastisity and correlated error terms within plants. R\&D intensity is measured as R\&D man-years per employee at the three-digit line of business level within firms. The sample consists of men with technical or scientific education employed full time in the machinery and equipment industry in Norway 1986-1995.

*** Significant at the $1 \%$ level

** Significant at the 5\% level

* Significant at the $10 \%$ level 


\section{Table 4. The effect of R\&D on the experience-earnings profile}

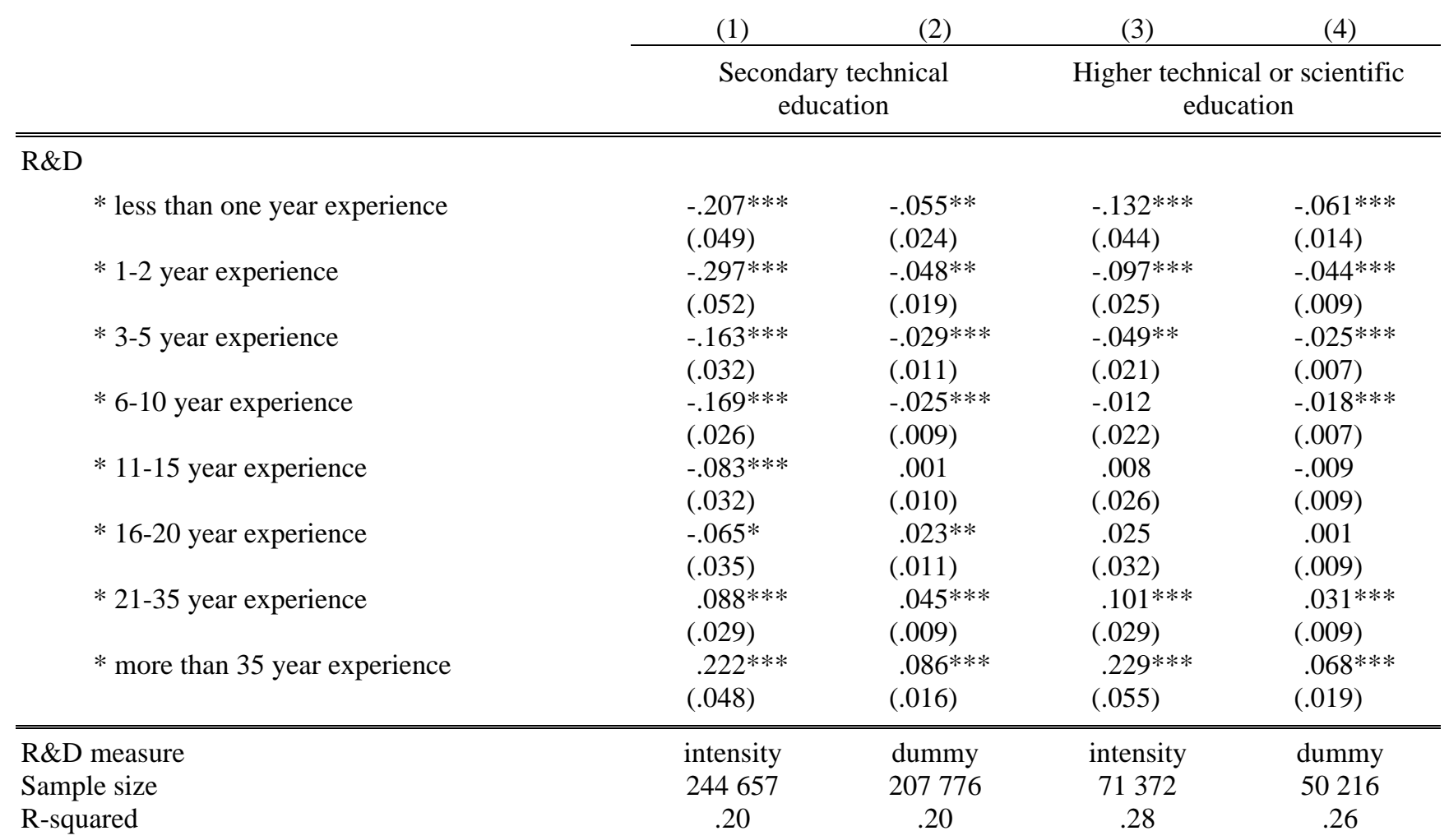

The dependent variable is ln (real annual earnings). Control variables included in the regression, but not reported are seven experience dummies, years of schooling, a quadratic in plant number of employees and year dummies. The coefficients are estimated using ordinary least squares. Standard errors, adjusted for heteroscedasticity and correlated error terms within individuals, are given in parentheses. $R \& D$ intensity is measured as R\&D man-years per employee at the three-digit line of business level within firms. The R\&D dummy is one if the R\&D intensity is above 0.2. Observations with R\&D-intensity between 0.05 and 0.2 are excluded from the regressions in column (2) and (4). The sample consists of men with technical or scientific education employed full time in the machinery and equipment industry in Norway 1986-1995.

*** Significant at the $1 \%$ level

** $\quad$ Significant at the 5\% level

* $\quad$ Significant at the $10 \%$ level 


\section{Table 5. The effect of $R \& D$ on biannual earnings growth}

Secondary technical education
Higher technical or scientific education

\footnotetext{
Stays with same employer from year $t-2$ to year $t$

* 2 year experience $* R \& D$-intensity

* 3-5 year experience * R\&D-intensity

* 6-10 year experience * R\&D-intensity

* 11-15 year experience * R\&D-intensity

* 16-20 year experience * R\&D-intensity

* 21-35 year experience * R\&D-intensity

* above 35 year experience * R\&D-intensity

Separates in year $t-1$

* 2-10 year experience $* \Delta R \& D$-intensity

* 11-20 year experience * $\Delta \mathrm{R} \& \mathrm{D}$-intensity

* above 21 year experience $* \Delta R \& D$-intensity
}

$\begin{array}{ll}-.203 * * & .021 \\ (.082) & (.040) \\ .077 * * * & .065^{* * *} \\ (.027) & (.017) \\ .079 * * * & .048 * * * \\ (.016) & (.012) \\ .101 * * * & .039 * * * \\ (.016) & (.014) \\ .093^{* * *} & .049 * * * \\ (.018) & (.015) \\ .063 * * * & .007 \\ (.011) & (.011) \\ .047 * * & .008 \\ (.022) & (.021)\end{array}$

$-.232 * * *$

$.097 * * *$

(.057)

(.037)

.044

.037

(.045)

$(.033)$

$-.076^{*}$

$-.021$

(.045)

(.040)

Sample size

139108

R-squared

.09

42466

.13

The dependent variable is the first difference of $\ln$ (real annual earnings) between year $t$ and year $t$-2. Control variables included in the regression, but not reported are cash flow before wage payments per employee, seven experience dummies, a dummy for being a separator in year $t$-linteracted with dummies for the three levels of experience used for separators, a quadratic in the change in plant size measured by number of employees and year dummies. The coefficients are estimated using ordinary least squares. Standard errors are given in parentheses. R\&D intensity is measured as R\&D man-years per employee at the three-digit line of business level within firms. R\&D intensity for stayers is the average over year $t, t-1$, and $t-2$. The sample consists of men with technical or scientific education employed full time in the machinery and equipment industry in Norway 1986-1995.

*** Significant at the $1 \%$ level

** Significant at the 5\% level

* Significant at the $10 \%$ level 


\section{Table 6. The effect of current $R \& D$ and previous $R \& D$ experience on earnings}

\begin{tabular}{|c|c|c|c|c|}
\hline & (1) & (2) & (3) & (4) \\
\hline & $\begin{array}{r}\text { Secondar } \\
\text { educ }\end{array}$ & anical & $\begin{array}{l}\text { Higher techni } \\
\text { educ }\end{array}$ & scientific \\
\hline & & & & \\
\hline * less than one year experience & $\begin{array}{l}-.204 * * * \\
(.050)\end{array}$ & $\begin{array}{l}-.204 * * * \\
(.050)\end{array}$ & $\begin{array}{l}-.134 * * * \\
(.044)\end{array}$ & $\begin{array}{l}-.130 * * * \\
(.044)\end{array}$ \\
\hline$* 1-2$ year experience & $\begin{array}{l}-.314 * * * \\
(.062)\end{array}$ & $\begin{array}{l}-.342 * * * \\
(.073)\end{array}$ & $\begin{array}{l}-.131 * * * \\
(.030)\end{array}$ & $\begin{array}{l}-.266^{* * * *} \\
(.038)\end{array}$ \\
\hline * 3-5 year experience & $\begin{array}{l}-.190 * * * \\
(.031)\end{array}$ & $\begin{array}{l}-.233 * * * \\
(.039)\end{array}$ & $\begin{array}{l}-.058 * * \\
(.023)\end{array}$ & $\begin{array}{l}-.123^{* * *} \\
(.027)\end{array}$ \\
\hline * 6-10 year experience & $\begin{array}{l}-.177 * * * \\
(.028)\end{array}$ & $\begin{array}{l}-.208 * * * \\
(.032)\end{array}$ & $\begin{array}{l}.010 \\
(.023)\end{array}$ & $\begin{array}{l}-.097 * * * \\
(.025)\end{array}$ \\
\hline$* 11-15$ year experience & $\begin{array}{l}-.080 * * \\
(.032)\end{array}$ & $\begin{array}{l}-.084 * * \\
(-.037)\end{array}$ & $\begin{array}{l}.014 \\
(.027)\end{array}$ & $\begin{array}{l}-.062 * * \\
(.069)\end{array}$ \\
\hline * 16-20 year experience & $\begin{array}{l}-.069 * \\
(.036)\end{array}$ & $\begin{array}{l}-.079 * \\
(.041)\end{array}$ & $\begin{array}{c}.031 \\
(.034)\end{array}$ & $\begin{array}{l}-.022 \\
(.038)\end{array}$ \\
\hline * 21-35 year experience & $\begin{array}{l}.089 * * * \\
(.029)\end{array}$ & $\begin{array}{c}.038 \\
(.030)\end{array}$ & $\begin{array}{l}.094 * * * \\
(.030)\end{array}$ & $\begin{array}{c}.039 \\
(.032)\end{array}$ \\
\hline * more than 35 year experience & $\begin{array}{l}.234 * * * \\
(.048)\end{array}$ & $\begin{array}{l}.285^{* * * *} \\
(.053)\end{array}$ & $\begin{array}{l}.222 * * * \\
(.056)\end{array}$ & $\begin{array}{l}.265^{* * * *} \\
(.062)\end{array}$ \\
\hline Average $R \& D$-intensity over previous & & & & \\
\hline * 1-2 year experience & & $\begin{array}{c}.055 \\
(.093)\end{array}$ & & $\begin{array}{l}.261 * * * \\
(.051)\end{array}$ \\
\hline * 3-5 year experience & & $\begin{array}{l}.094 \\
(.057)\end{array}$ & & $\begin{array}{l}.142 * * * \\
(.038)\end{array}$ \\
\hline * 6-10 year experience & & $\begin{array}{l}.070 \\
(.055)\end{array}$ & & $\begin{array}{l}.186^{* * * *} \\
(.036)\end{array}$ \\
\hline$* 11-15$ year experience & & $\begin{array}{l}.010 \\
(.062)\end{array}$ & & $\begin{array}{l}.167 * * * \\
(.038)\end{array}$ \\
\hline * 16-20 year experience & & $\begin{array}{c}.028 \\
(.059)\end{array}$ & & $\begin{array}{l}.134 * * * \\
(.052)\end{array}$ \\
\hline * 21-35 year experience & & $\begin{array}{l}.171 * * * \\
(.060)\end{array}$ & & $\begin{array}{l}.165^{* * * *} \\
(.053)\end{array}$ \\
\hline * more than 35 year experience & & $\begin{array}{l}-.158^{* *} \\
(.072)\end{array}$ & & $\begin{array}{c}-0.149 \\
(.103)\end{array}$ \\
\hline Sample size & 227418 & 227418 & 65422 & 65422 \\
\hline $\mathrm{R}$-squared & .19 & .19 & .28 & .28 \\
\hline
\end{tabular}

The dependent variable is ln (real annual earnings). Control variables included in the regression, but not reported, are seven experience dummies, years of schooling, a quadratic in plant number of employees and year dummies. The coefficients are estimated using ordinary least squares. Standard errors, adjusted for heteroscedasticity and correlated error terms within individuals, are given in parentheses. $R \& D$ intensity is measured as R\&D man-years per employee at the three-digit line of business level within firms. The sample consists of men with technical or scientific education employed full time in the machinery and equipment industry in Norway 1986-1995. Workers, for whom no R\&D information from previous years is available, have been excluded.

*** Significant at the $1 \%$ level

** Significant at the 5\% level

* Significant at the $10 \%$ level 


\section{Table 7. The effect of current R\&D, R\&D experience from the current employer and $R \& D$ experience from previous employers}

\begin{tabular}{|c|c|c|c|c|}
\hline & $(1)$ & (2) & (3) & (4) \\
\hline & $\begin{array}{r}\text { Secondar } \\
\text { edu }\end{array}$ & hnical & $\begin{array}{r}\text { Higher techn } \\
\text { edu }\end{array}$ & $\begin{array}{l}\mathrm{r} \text { scientific } \\
\mathrm{n}\end{array}$ \\
\hline current $\mathrm{R} \& \mathrm{D}$ intensity & $\begin{array}{l}-.316 * * * \\
(.042)\end{array}$ & $\begin{array}{l}-.480 * * * \\
(.063)\end{array}$ & $\begin{array}{l}-.104 * * * \\
(.034)\end{array}$ & $\begin{array}{l}-.157 * * * \\
(.052)\end{array}$ \\
\hline * experience & $.017 * * *$ & $.038 * * *$ & .003 & .008 \\
\hline & $(.002)$ & $(.008)$ & $(.002)$ & $(.007)$ \\
\hline$*$ experience $^{2}$ & & $-.001 * * *$ & & -.0001 \\
\hline & & $(.0002)$ & & $(.0002)$ \\
\hline $\begin{array}{l}\text { mean } R \& D \text { intensity in previou } \\
\text { employer }\end{array}$ & & & & \\
\hline * tenure & $.028 * * *$ & $.124 * * *$ & $.032 * * *$ & $.089 * * *$ \\
\hline & $(.008)$ & $(.018)$ & $(.007)$ & $(.014)$ \\
\hline$*$ tenure $^{2}$ & & $-.014 * * *$ & & $-.008 * * *$ \\
\hline & & $(.002)$ & & $(.002)$ \\
\hline mean $R \& D$ intensity in years $w$ & & & & \\
\hline$*($ experience - tenure $)$ & $.008^{* *}$ & .005 & $.005^{* *}$ & $.013 * *$ \\
\hline & $(.003)$ & $(.008)$ & $(.002)$ & $(.006)$ \\
\hline$*(\text { experience }- \text { tenure })^{2}$ & & .0001 & & -.0004 \\
\hline & & $(.0003)$ & & $(.0003)$ \\
\hline Sample size & 62243 & 62243 & 17675 & 17675 \\
\hline R-squared & .23 & .24 & .33 & .33 \\
\hline
\end{tabular}

The dependent variable is ln (real annual earnings). Control variables included in the regression, but not reported, are years of schooling, a quadratic in plant number of employees, a quartic in experience, a quadratic in tenure, a dummy for having changed employer at least once, year dummies and a dummy variable for job relationships whose starting date is censored at April $30^{\text {th }} 1978$ together with its interactions with all tenure variables. The coefficients are estimated using ordinary least squares. Standard errors, adjusted for heteroscedastisity and correlated error terms within individuals, are given in parentheses. $R \& D$ intensity is measured as $R \& D$ man-years per employee at the three-digit line of business level within firms. Mean R\&D intensity is calculated over the years where information about the R\&D intensity is available. The sample consists of men with technical or scientific education employed full time in the machinery and equipment industry in Norway 1986-1995. Workers in firms where R\&D information is not available in the sample year and in at least one prior year, and workers who have had previous employment without R\&D intensity being known in at least one year, have been excluded.

*** Significant at the $1 \%$ level

** Significant at the $5 \%$ level

* Significant at the $10 \%$ level 


\section{Table A1. Sample size and trimming procedures}

Total number of observations in the machinery and equipment industries 1986-1995

810559

- Women

- Part time workers

- Workers with unknown education

- Workers with primary education

- Workers with secondary or higher non-technical/non-scientific education

Total number of observations of full time working male technical staff

- Workers in firms that cannot be matched to the time series files of the manufacturing statistics

- Workers in firms where R\&D information is not available

Total number of observations of full time working male technical staff in the matched sample

- Workers not working for the whole year because they are entering the labor force

- Workers not working for the whole year because they are leaving the labor force

- Workers with secondary technical education and earnings below NOK 75.000 (1995 value)

- Workers with higher technical or scientific education and earnings below NOK 150.000 (1995 value)
125111

11314

8968

141216

94325

429625

39527

46744

343354

9982

14044

2723

566

316029

Each entry refers to the number of observations deleted among the observations left after the deletions in the rows above have been conducted. Workers with secondary technical education and earnings below NOK 75.000 (1995 value), and workers with higher technical or scientific education and earnings below NOK 150.000 (1995 value) have been excluded because such low earnings suggest that they have not worked full time for an entire year. Tables 1-3 are based on all observations of full time working male technical staff in the matched sample, whereas the wage regressions in tables 4-7 are based on the trimmed 'main sample'. 
Table A2. Observations in main sample by year and education

\begin{tabular}{lccc} 
Number of & $\begin{array}{c}\text { Secondary technical } \\
\text { education }\end{array}$ & $\begin{array}{c}\text { Higher technical or } \\
\text { scientific education }\end{array}$ \\
\hline \hline 1986 & 29256 & $75.0 \%$ & $25.0 \%$ \\
1987 & 30329 & $75.8 \%$ & $24.2 \%$ \\
1988 & 29450 & $76.0 \%$ & $24.0 \%$ \\
1989 & 29952 & $76.2 \%$ & $23.8 \%$ \\
1990 & 31576 & $77.1 \%$ & $22.9 \%$ \\
1991 & 31482 & $79.6 \%$ & $20.4 \%$ \\
1992 & 33857 & $79.2 \%$ & $20.8 \%$ \\
1993 & 33261 & $78.8 \%$ & $21.2 \%$ \\
1994 & 35315 & $78.3 \%$ & $21.7 \%$ \\
1995 & 31551 & $77.4 \%$ & $22.6 \%$ \\
\hline \hline Observations & 316029 & $77.4 \%$ & $22.6 \%$
\end{tabular}

Table A3. Observations in the main sample by experience and $R \& D$ intensity

\begin{tabular}{|c|c|c|c|c|c|}
\hline & Observations & No $R \& D$ & $\begin{array}{c}\text { R\&D-intensity } \\
\quad \in\langle 0, .05]\end{array}$ & $\begin{array}{c}\mathrm{R} \& \mathrm{D} \text {-intensity } \\
\quad \in\langle .05, .2]\end{array}$ & $\begin{array}{c}\mathrm{R} \& \mathrm{D} \text {-intensity } \\
>.2\end{array}$ \\
\hline Less than one year experience & 7017 & $36.6 \%$ & $42.9 \%$ & $16.5 \%$ & $4.0 \%$ \\
\hline 1-2 year experience & 18446 & $36.8 \%$ & $40.3 \%$ & $16.9 \%$ & $6.0 \%$ \\
\hline 3-5 year experience & 36167 & $37.7 \%$ & $37.7 \%$ & $17.6 \%$ & $7.0 \%$ \\
\hline $6-10$ year experience & 57802 & $42.1 \%$ & $32.8 \%$ & $17.5 \%$ & $7.5 \%$ \\
\hline $11-15$ year experience & 44545 & $41.0 \%$ & $32.3 \%$ & $19.3 \%$ & $7.4 \%$ \\
\hline $16-20$ year experience & 37563 & $42.9 \%$ & $32.0 \%$ & $18.6 \%$ & $6.4 \%$ \\
\hline 21-35 year experience & 86846 & $40.6 \%$ & $33.9 \%$ & $19.3 \%$ & $6.2 \%$ \\
\hline \multirow[t]{2}{*}{ More than 35 year experience } & 27643 & $41.4 \%$ & $35.7 \%$ & $17.8 \%$ & $5.1 \%$ \\
\hline & 310027 & $40.6 \%$ & $34.4 \%$ & $18.4 \%$ & $6.6 \%$ \\
\hline
\end{tabular}

R\&D intensity is measured as R\&D man-years per employee at the three-digit line of business level within firms. 
Table A4. Worker characteristics by education

\begin{tabular}{|c|c|c|}
\hline & $\begin{array}{c}\text { Secondary technical } \\
\text { education }\end{array}$ & $\begin{array}{l}\text { Higher technical or } \\
\text { scientific education }\end{array}$ \\
\hline \multicolumn{3}{|l|}{ Years of education } \\
\hline mean & 11.2 & 14.5 \\
\hline st.dev. & $(.9)$ & (1.7) \\
\hline $10^{\text {th }}$ percentile & 10.0 & 13.0 \\
\hline $90^{\text {th }}$ percentile & 12.0 & 17.0 \\
\hline \multicolumn{3}{|l|}{ Years of experience } \\
\hline mean & 16.8 & 17.4 \\
\hline st.dev. & (11.9) & (11.6) \\
\hline $10^{\text {th }}$ percentile & 3 & 3 \\
\hline $90^{\text {th }}$ percentile & 34 & 35 \\
\hline \multicolumn{3}{|l|}{ Years of tenure } \\
\hline mean & 6.3 & 6.0 \\
\hline st.dev. & (5.6) & (5.1) \\
\hline $10^{\text {th }}$ percentile & .9 & .9 \\
\hline $90^{\text {th }}$ percentile & 13.2 & 12.5 \\
\hline \multicolumn{3}{|l|}{ Wage in 1995 NOK } \\
\hline mean & 245400 & 353500 \\
\hline st.dev. & $(71000)$ & (125 900) \\
\hline $10^{\text {th }}$ percentile & 176500 & 240200 \\
\hline $90^{\text {th }}$ percentile & 336100 & 479700 \\
\hline \multicolumn{3}{|l|}{ Union membership } \\
\hline share & $44 \%$ & $27 \%$ \\
\hline \multicolumn{3}{|c|}{ Working at R\&D performing plant } \\
\hline share & $54 \%$ & $78 \%$ \\
\hline \multicolumn{3}{|c|}{$R \& D$-intensity if at $R \& D$ performing plant } \\
\hline mean & .057 & .125 \\
\hline st.dev. & $(.085)$ & $(.134)$ \\
\hline $10^{\text {th }}$ percentile & .002 & .006 \\
\hline $90^{\text {th }}$ percentile & .152 & .278 \\
\hline
\end{tabular}

The numbers are based on all worker-year observations in the machinery and equipment industry included in the main sample, cf. table A1. An R\&D plant is a plant belonging to a firm that conducts some R\&D within the plant's three-digit ISIC industry. R\&D intensity is measured as R\&D man-years per employee at the three-digit line of business level within firms. Wage in $1995 \mathrm{NOK}$ is rounded to the nearest 100.

$\$ 16$ percent of the observations have the job starting date censored at April $30^{\text {th }} 1978$. 
Table A5. Plant characteristics by plant size

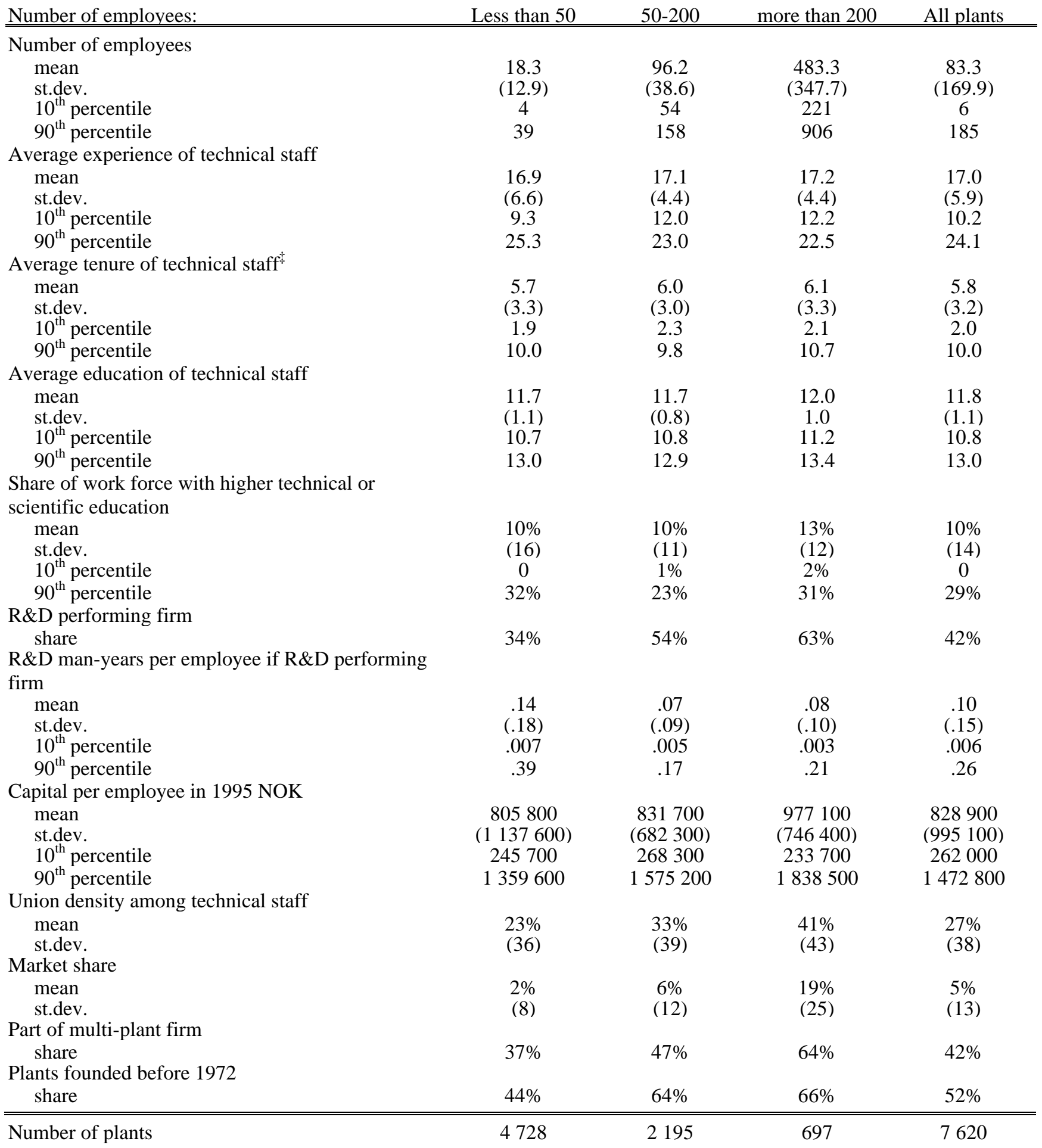

The numbers are based on all plant-year observations in the machinery and equipment industries included in the main sample, cf. table A1. An R\&D plant is a plant belonging to a firm that conducts some R\&D within the plants three-digit ISIC industry. R\&D man-years per employee and R\&D sales ratio are measured at the three-digit line of business level within firms. Market share is measured at the five-digit line of business level for the firm that the plant belongs to. Capital per employee is rounded to the nearest 100 .

16 percent of the underlying employee observations have the job starting date censored at April $30^{\text {th }} 1978$. 


\section{Table A6. Aggregate growth from 1986 to 1995 and R\&D intensity by sub-industries}

\begin{tabular}{|c|c|c|c|c|c|c|c|c|}
\hline \multirow[b]{2}{*}{ ISIC } & & \multicolumn{3}{|c|}{ Number of plants } & \multicolumn{3}{|c|}{ Number of observations } & \multirow{2}{*}{$\begin{array}{c}\text { R\&D } \\
\text { intensity }\end{array}$} \\
\hline & & 1986 & 1995 & $\Delta$ & 1986 & 1995 & $\Delta$ & \\
\hline 38210 & Engines and turbines & 9 & 11 & 2 & 939 & 856 & $-9 \%$ & .03 \\
\hline 38220 & Agricultural machinery & 52 & 33 & -19 & 514 & 597 & $16 \%$ & .04 \\
\hline 38230 & Metal and wood-working machinery & 37 & 26 & -11 & 200 & 183 & $-9 \%$ & .04 \\
\hline 38241 & Oil and gas well machinery and tools & 92 & 104 & 12 & 4709 & 8270 & $76 \%$ & .02 \\
\hline 32249 & Other industrial machinery & 73 & 104 & 31 & 607 & 878 & $45 \%$ & .06 \\
\hline 38250 & Computers and office machinery & 50 & 28 & -22 & 1052 & 334 & $-68 \%$ & 26 \\
\hline 38291 & Household machinery & 11 & 8 & -3 & 95 & 92 & $-3 \%$ & .04 \\
\hline 38292 & Repair of machinery & 709 & 458 & -251 & 480 & 594 & $24 \%$ & 11 \\
\hline 38299 & Other machinery & 339 & 351 & 12 & 4132 & 3197 & $-23 \%$ & .09 \\
\hline 38310 & Electric motors and eq. for el. production & 139 & 153 & 14 & 2428 & 2010 & $-17 \%$ & .07 \\
\hline 38320 & Radio, TV and communication apparatus & 190 & 135 & -55 & 3335 & 2858 & $-14 \%$ & 17 \\
\hline 38330 & Electrical household appliances & 32 & 20 & 12 & 251 & 187 & $-25 \%$ & 12 \\
\hline 38391 & Insulated cables and wires & 12 & 17 & 5 & 689 & 627 & $-9 \%$ & 12 \\
\hline 38399 & Other electrical apparatus and equipment & 124 & 100 & -24 & 596 & 282 & $-53 \%$ & .04 \\
\hline 38411 & Building of ships & 163 & 188 & -25 & 3738 & 4350 & $16 \%$ & .01 \\
\hline 38412 & Building of boats & 438 & 232 & -206 & 535 & 400 & $-25 \%$ & .04 \\
\hline 38413 & Ship and boat engines and motors & 36 & 29 & -7 & 557 & 353 & $-37 \%$ & .04 \\
\hline 38414 & Components and fixtures for ships/boats & 53 & 55 & 2 & 590 & 981 & $66 \%$ & .02 \\
\hline 38421 & Railway and tramway equipment & 1 & 1 & 0 & 136 & 178 & $31 \%$ & - \\
\hline 38422 & Repair of railway and tramway eq. & 18 & 8 & -10 & 1258 & 1015 & $-19 \%$ & - \\
\hline 38430 & Motor vehicles & 174 & 80 & -94 & 740 & 1207 & $63 \%$ & .06 \\
\hline 38440 & Motor cycles and bicycles & 1 & 2 & 1 & 114 & 77 & $-32 \%$ & - \\
\hline 38450 & Aircraft & 28 & 20 & -8 & 1167 & 1173 & $1 \%$ & .01 \\
\hline 38490 & Other transport eq & 6 & 12 & 6 & 11 & 52 & $373 \%$ & .02 \\
\hline 38510 & Professional and scientific instruments & 57 & 109 & 52 & 306 & 749 & $145 \%$ & 11 \\
\hline 38520 & Photographic and optical goods & 10 & 8 & -2 & 77 & 51 & $-34 \%$ & .22 \\
\hline 382-385 & All machinery and equipment industries & 24 & 292 & 62 & 863 & 698 & $19 \%$ & 10 \\
\hline
\end{tabular}

The number of plants is taken from the manufacturing census. The number of observations refers to the technical staff in the main sample, cf. table A1. The growth in the technical staff does not imply that there has been employment growth in these industries, but is a result of old workers with primary education not included in the sample, gradually being replaced by workers with secondary education. R\&D-intensity is the weighted average R\&D man-years per employee, measured at the three-digit line of business level within firms, for the plants in the sample over the years 1986-1995. 